\title{
Productive Response of Brassica rapa L. subsp. chinensis to Application of VIUSID Agro
}

\author{
Kolima Peña Calzada, ${ }^{1,2}$, Dilier Olivera Viciedo ${ }^{1,2}$, Alexander Calero ${ }^{2}$, Juan Carlos Rodríguez ${ }^{1}$, Bulent Kukurtcu ${ }^{3}$, \\ Yanet Milagros Placencia Álvarez ${ }^{1}$ and Alexei Castro Salas ${ }^{4}$ \\ 1. Department of Agronomy, Faculty of Agricultural Sciences, University of Sancti Spiritus Jose Marti Perez (UNISS), Sancti \\ Spiritus 60100, Cuba \\ 2. School of Agricultural and Veterinarian Sciences, São Paulo State University (UNESP), Jaboticabal 1480, São Paulo, Brazil \\ 3. Scientific Department, Catalysis, S.L., Madrid 28016, Spain \\ 4. Department of Mathematics, University of Camagüey Ignacio Agramonte Loynaz, Camagüey 74650, Cuba
}

\begin{abstract}
In order to evaluate the effect of VIUSID agro on the yield response of a pak choi harvest, a randomised block experiment was designed with four treatments and three replications. The treatments were dosages of $0.1,0.2$ and $0.3 \mathrm{~L} / \mathrm{ha}$ and one control. The number of leaves per plant and the fresh and dry mass of the plant were measured. In addition, growth indexes were evaluated, such as relative growth rate, active growth rate, harvest index and agricultural yield. The number of leaves per plant was significantly greater at 35 days after sowing (das) for $0.2 \mathrm{~L} /$ ha and $0.3 \mathrm{~L} /$ ha treatments, with increases of $15.0 \%$ and $14.17 \%$ relative to the control. Regarding plant length and fresh mass at the final evaluation, the treatments using higher dosages produced the best results. Regarding the active growth rate, the $0.2 \mathrm{~L} / \mathrm{ha}$ dosage produced the best effects, and regarding relative growth rate, the $0.2 \mathrm{~L} / \mathrm{ha}$ and $0.3 \mathrm{~L} / \mathrm{ha}$ dosages produced the best results relative to the control. The harvest index did not benefit from the used dosages, while a higher agricultural yield was achieved using the $0.2 \mathrm{~L} / \mathrm{ha}$ and $0.3 \mathrm{~L} / \mathrm{ha}$ dosages at $18.03 \%$ and $12.88 \%$ compared to the control. Therefore, VIUSID agro positively influenced the yield behaviour of pak choi.
\end{abstract}

Key words: VIUSID agro, pak choi, amino acids, vegetables.

\section{Introduction}

Vegetables are essential for the human diet. The amount of cellulose and high water content contained in their tissues facilitate the digestive process. Among them, pak choi (Brassica rapa) is very important because it has medicinal properties and is a natural expectorant and digestive stimulant [1]. It is a species that is usually cultivated in small quantities and limited areas compared to other horticultural crops. Pak choi features a short cycle that allows for rational land use and it can be cultivated year-round, although the highest yields are achieved in tropical regions during the season with the lowest temperatures [2].

Among the varieties of leaf vegetables are two

Corresponding author: Kolima Peña Calzada, professor, research field: vegetable physiology and nutrition. fundamental types: Asian types, where the whole plant is harvested at once, and which may have a white or green petiole, and Western types, whose leaves are harvested in different cuts and not all at once, where transplantation is the most highly recommended sowing method in both cases, being able to reach eight or more rotations per year [3]. In Cuba, this crop has low yield levels since it is farmed in a small area and in association with other vegetables, most commonly in protected organoponics and growing sheds. The purpose of these small production units in urban areas, known as organoponics, whose surface areas do not exceed 3 ha, is to grow fresh vegetables and high-quality herbs in order to meet needs of the population, due to the role they play in the daily family diet [4]. Organoponic yields tend to be from $2.0 \mathrm{~kg} / \mathrm{m}^{2}$ to $2.5 \mathrm{~kg} / \mathrm{m}^{2}$ and can 
reach up to $3.5 \mathrm{~kg} / \mathrm{m}^{2}$ with the Canton variety of pak choi [3].

Around 202,128 ha of vegetable crops are cultivated annually in Cuba to obtain 2,498,960 t. The largest yields are from tomatoes (Solanum lycopersicum L.), onions (Allium cepa L.) and sweet peppers (Capsicum annum L.) at 627,434 t between the three, according to the Statistical Yearbook of Cuba [5]. However, other vegetable yields are still low and inverse to the current high demand, nor are they reflected per crop in the statistics offered in the yearbook. In this sense, it is important to look for alternatives to increase the vegetable crops yield. One alternative to evaluate in this sense is the growth promoter VIUSID agro, to act as a natural bioregulator and it is essentially composed of amino acids, vitamins and minerals. Another relevant aspect is that all these compounds are subjected to a molecular activation process that allows for the use of relatively low dosages with good results [6].

Evaluations of this product have been carried out on different crops, including grasses [7, 8] anthurium (Anthurium andreanum Lind.) [9], tomatoes ( $S$. lycopersicum) [10], corn (Zea mays L.) [11], onion (A. сера) [12] and vegetables, including radishes (Raphanus sativus) [13, 14]. These evaluations have allowed for the exploration of the advantages of the product. However, the studies are still insufficient, given the fact that reproductions with different species, varieties and repetitions over time are required for agricultural research [15]. For this reason, the purpose of the research was to determine the yield response of pak choi (B. rapa subsp. chinensis (L. Manelt)) to application of VIUSID agro.

\section{Materials and Methods}

\subsection{General Aspects of the Research}

The research was carried out at an organoponic garden in the town of Sancti Spiritus, Cuba, located at the coordinates $\left(21^{\circ} 55^{\prime} 49.60^{\prime \prime} \mathrm{N}, 79^{\circ} 26^{\prime} 10.83^{\prime \prime} \mathrm{W}\right)$. The used variety in the experiment was PK-7 from the seed company, with $85 \%$ germination. The climatic variables were registered by the Sancti Spiritus Provincial Station; the average daily temperature was $21.85{ }^{\circ} \mathrm{C}$, with an average daily relative humidity of $75.20 \%$ and accumulated rainfall of $22.98 \mathrm{~mm}$. The sowing date was Sep. 27th, 2017 and the date of harvest was Nov. 1st of the same year. The substrate, irrigation, pest and disease control and agro-technical management were established according to the technical manual for organoponics [3].

\subsection{Experimental Design, Means of Applications and Treatments}

The experimental design was random blocks with four treatments and three repetitions. The plots were 6 $\mathrm{m}^{2}$ and the calculated surface was $4 \mathrm{~m}^{2}$. The sowing frame was $0.10 \mathrm{~m} \times 0.15 \mathrm{~m}$. Twenty plants were randomly marked per parcel for a total of 60 plants evaluated for treatment. The applications of VIUSID, were performed in the first time from emergence of the first leaves and during the first morning hours with a weekly frequency, until a week before harvest, for a total of four applications, during 5, 12, 19 and 26 October 2017, respectively. The treatments included a control with no application and VIUSID agro $(0.1,0.2$, and $0.3 \mathrm{~L} / \mathrm{ha}$ ). The product composition is presented in Table 1.

All these compounds underwent a molecular activation process. Different indicators were evaluated as: leaves number per plant, length $(\mathrm{cm})$, fresh mass $(\mathrm{g})$, active and relative growth rate $\left(\mathrm{kg} / \mathrm{m}^{2}\right)$. These indicators were evaluated at 25 days after sowing (das) and during harvest, 35 das. Leaves per plant were counted and recorded and then were oven-dried ((MJW WS 100, Memmert's, Berlin, Federal Republic of Germany) at $60 \pm 5{ }^{\circ} \mathrm{C}$ until a constant weight using a Sartorius digital scale with $\pm 0.001 \mathrm{~g}$ of precision. All treatments were kept within the established range [16] for the harvest. Yield was calculated using the indirect method [15] and growth indexes according to the following procedure (Table 2). 
Table 1 Composition of the evaluated growth promoter.

\begin{tabular}{llll}
\hline Composition & $\mathrm{g} / 100 \mathrm{~mL}$ & Composition & $\mathrm{g} / 100 \mathrm{~mL}$ \\
\hline Potassium phosphate & 5 & Calcium pantothenate & 0.115 \\
Malic acid & 4.6 & Pyridoxal & 0.225 \\
Glucosamine & 4.6 & Folic acid & 0.05 \\
Arginine & 4.15 & Cyanocobalamin & 0.0005 \\
Glycine & 2.35 & Monoammonium glycyrrhizinate & 0.23 \\
Ascorbic acid & 1.15 & Sodium benzoate & 0.2 \\
Zinc sulphate & 0.115 & Potassium sorbate & 0.2 \\
Distilled water-quantum sufficit (q.s.) & $100 \mathrm{~mL}$ & & \\
\hline
\end{tabular}

Table 2 Growth indexes used in plant physiology [17].

\begin{tabular}{llll}
\hline Growth rate & Symbol & Formula & Units \\
\hline Absolute growth rate & AGR & AGR $=(\mathrm{W} 2-\mathrm{W} 1) /(\mathrm{T} 2-\mathrm{T} 1)$ & $\mathrm{g} / \mathrm{d}$ \\
Relative growth rate & RGR & $\mathrm{RGR}=2(\mathrm{~W} 2-\mathrm{W} 1) /(\mathrm{W} 2+\mathrm{W} 1)(\mathrm{T} 2-\mathrm{T} 1)$ & $\mathrm{g} / \mathrm{g} / \mathrm{d}$ \\
Harvest index & HI & HI $=$ Commercial dry mass/Total dry mass & \\
\hline
\end{tabular}

$\mathrm{W}=$ dry mass, $\mathrm{T}=$ time.

\subsection{Statistics}

Statistical analysis was carried out using statistics suite [18] version 15.0 for Windows and the MINITAB 14.12.0 software [19]. The Kolmogorov-Smirnov test was used for normality and Levene test for homogeneity of variance. For when normality and homogeneity existed in conjunction, a simple analysis of variance (ANOVA) and Tukey test at 5\% probability level. The Kruskal-Wallis test and the Mann-Whitney $U$ test were applied when the data were not normally distributed.

\section{Results and Discussion}

\subsection{Effect of Treatments on the Number of Leaves and Plant Length at 15 DAS and 30 DAS}

Table 3 shows the effects of treatments on the number of leaves per plant. At the first evaluation, no significant differences $(p<0.05)$ existed between treatments and at the second, the most favourable behaviour was achieved with the $0.2 \mathrm{~L} / \mathrm{ha}$ and 0.3 L/ha treatments, with significant differences when compared to the lower dosage and the control. The increases in this regard were $15.0 \%$ and $14.17 \%$. Regarding plant length the $0.2 \mathrm{~L} / \mathrm{ha}$ and $0.3 \mathrm{~L} / \mathrm{ha}$ treatments differed significantly from the control with an increase $12.73 \%$ and $12.50 \%$ at 25 das and $17.30 \%$ and $15.62 \%$ at last evaluation. Treatment with the 0.1 L/ha dosage did not differ significantly from the control in the evaluations performed.

No other reports were found confirming that VIUSID agro promotes an increase in the number of leaves and plant length in pak choi crops. However, Peña et al. [9] found favourable results in the number of leaves per plant in an anthurium (A. andreanum) crop upon foliar application of VIUSID agro.

\subsection{Effect of Treatments on Fresh and Dry Mass of Plants at 15 DAS and 30 DAS}

Only the results achieved with the $0.2 \mathrm{~L} /$ ha dosage had significantly statistical differences on the dry mass of plants $15 \mathrm{~d}$ subsequent to sowing relative to the control. At 30 das, the lower dosage obtained unfavourable behaviour and the $0.2 \mathrm{~L} /$ ha and $0.3 \mathrm{~L} /$ ha treatments significantly differed from the variant without VIUSID agro, surpassing the latter by $18.05 \%$ and $12.86 \%$ (Table 4 ).

There were no significant differences between treatments in the dry mass of the plants at the first evaluation. However, at $30 \mathrm{das}$, the $0.2 \mathrm{~L} / \mathrm{ha}$ treatment had a favourable effect on increase in mass with significant differences in relation to the rest of the 
Table 3 Effect of treatments on the number of leaves and plant length of pak choi.

\begin{tabular}{lllll}
\hline \multirow{2}{*}{ Treatments } & \multicolumn{2}{c}{ Number of leaves } & \multicolumn{2}{c}{ Length of the plant $(\mathrm{cm})$} \\
\cline { 2 - 5 } & 25 das & 35 das & 25 das & 35 das \\
\hline Control & $5.50^{\mathrm{a}}$ & $6.00^{\mathrm{b}}$ & $25.45^{\mathrm{b}}$ & $30.46^{\mathrm{b}}$ \\
$0.1 \mathrm{~L} / \mathrm{ha}$ & $5.71^{\mathrm{a}}$ & $6.25^{\mathrm{b}}$ & $25.49^{\mathrm{b}}$ & $31.92^{\mathrm{b}}$ \\
$0.2 \mathrm{~L} / \mathrm{ha}$ & $5.67^{\mathrm{a}}$ & $6.90^{\mathrm{a}}$ & $28.69^{\mathrm{a}}$ & $35.73^{\mathrm{a}}$ \\
$0.3 \mathrm{~L} / \mathrm{ha}$ & $5.66^{\mathrm{a}}$ & $6.85^{\mathrm{a}}$ & $28.63^{\mathrm{a}}$ & $35.24^{\mathrm{a}}$ \\
$\mathrm{SE}$ & 0.12 & 0.09 & 0.24 & 0.30 \\
$\mathrm{CV}$ & 19.83 & 16.37 & 9.08 & 9.60 \\
\hline
\end{tabular}

$\mathrm{SE}=$ standard error; $\mathrm{CV}=$ coefficient of variation; das: days after sowing. Means with different letters in the same column vary significantly number of leaves by Tukey test at $5 \%$ probability level, and the Kruskal-Wallis and Mann-Whitney $U$ tests for plant length at 25 das.

Table 4 Effects of treatments on fresh and dry mass of the plants.

\begin{tabular}{lllll}
\hline \multirow{2}{*}{ Treatments } & \multicolumn{2}{c}{ Fresh mass of the plant $(\mathrm{g})$} & \multicolumn{2}{c}{ Dry mass of the plant $(\mathrm{g})$} \\
\cline { 2 - 5 } & 25 das & 35 das & 25 das & 35 das \\
\hline Control & $19.70^{\mathrm{b}}$ & $32.35^{\mathrm{b}}$ & $0.83^{\mathrm{a}}$ & $1.49^{\mathrm{b}}$ \\
$0.1 \mathrm{~L} / \mathrm{ha}$ & $20.34^{\mathrm{b}}$ & $34.39^{\mathrm{b}}$ & $0.84^{\mathrm{a}}$ & $1.59^{\mathrm{b}}$ \\
$0.2 \mathrm{~L} / \mathrm{ha}$ & $23.19^{\mathrm{a}}$ & $38.19^{\mathrm{a}}$ & $0.90^{\mathrm{a}}$ & $1.77^{\mathrm{a}}$ \\
$0.3 \mathrm{~L} / \mathrm{ha}$ & $21.04^{\mathrm{b}}$ & $36.51^{\mathrm{a}}$ & $0.89^{\mathrm{a}}$ & $1.60^{\mathrm{b}}$ \\
$\mathrm{SE}$ & 0.77 & 1.40 & 0.03 & 0.07 \\
$\mathrm{CV}$ & 26.26 & 28.95 & 26.67 & 23.75 \\
\hline
\end{tabular}

$\mathrm{SE}=$ standard error; $\mathrm{CV}=$ coefficient of variation; das: days after sowing. Means with different letters in the same column vary significantly by Tukey test at $5 \%$ probability level.

treatments, increasing $18.79 \%$ with respect to the control (Table 4). The obtained results can be attributed to the use of VIUSID agro, because in the composition of this growth enhancer has several elements that have a positive influence on plant growth and therefore on the increase of fresh and dry mass catalysis [6]. These include pyridoxal, potassium phosphate, folic acid and amino acids such as glycine. In addition, particular importance is given to the biocatalytic process of molecular activation, where molecules are activated to obtain a greater effect on the crops from these components.

On the other hand, the total production of dry mass is a result of the efficiency of the crop's foliage in the interception and use of the solar radiation available during the growth cycle [19]. In this sense, the treatments with VIUSID agro had better results in comparison to the control. Results analogous to those obtained from this investigation were obtained in several vegetables as beets, lettuce and radishes, where the foliar application of VIUSID agro increased the fresh and dry mass of the plants [13].

\subsection{Effect of Treatments on the Absolute Growth Rate, Relative Growth Rate, Harvest Index and Yield}

Table 5 shows that the best absolute growth rate was obtained from the $0.2 \mathrm{~L} /$ ha dosage, which was significantly different from the rest of the treatments, with an increase of $0.021 \mathrm{~g} / \mathrm{d}$ relative to the control. This means that the variant mentioned had a daily dry mass production $31.82 \%$ greater than the control. The $0.1 \mathrm{~L} / \mathrm{ha}$ dose also differed significantly from the treatment that did not use VIUSID agro, with a respective increase of $0.009 \mathrm{~g} / \mathrm{d}$, which represented an increase of $13.64 \%$.

As observed the relative growth rate, and likewise, all treatments with VIUSID agro significantly surpassed the control except for the highest dosage (Table 5). The most favourable behaviour was achieved with the $0.1 \mathrm{~L} / \mathrm{ha}$ and $0.2 \mathrm{~L} /$ ha dosages, with significant differences with respect to the rest of the treatments and an increase of $10.71 \%$ and $16.07 \%$ relative 
Table 5 Effects of treatments on the AGR, RGR and HI.

\begin{tabular}{llll}
\hline Treatments & AGR $(\mathrm{g} / \mathrm{d})$ & RGR $(\mathrm{g} / \mathrm{g} / \mathrm{d})$ & $\mathrm{HI}$ \\
\hline Control & $0.066^{\mathrm{c}}$ & $0.056^{\mathrm{b}}$ & $0.94^{\mathrm{a}}$ \\
$0.1 \mathrm{~L} / \mathrm{ha}$ & $0.075^{\mathrm{b}}$ & $0.062^{\mathrm{a}}$ & $0.96^{\mathrm{a}}$ \\
$0.2 \mathrm{~L} / \mathrm{ha}$ & $0.087^{\mathrm{a}}$ & $0.065^{\mathrm{a}}$ & $0.95^{\mathrm{a}}$ \\
$0.3 \mathrm{~L} / \mathrm{ha}$ & $0.071^{\mathrm{bc}}$ & $0.057^{\mathrm{b}}$ & $0.95^{\mathrm{a}}$ \\
$\mathrm{SE}$ & 0.0001 & 0.002 & 0.03 \\
$\mathrm{CV}$ & 20.05 & 21.34 & 19.18 \\
\hline
\end{tabular}

$\mathrm{SE}=$ standard error; $\mathrm{CV}=$ coefficient of variation. Means with different letters in the same column vary significantly by Tukey test at $5 \%$ probability level.

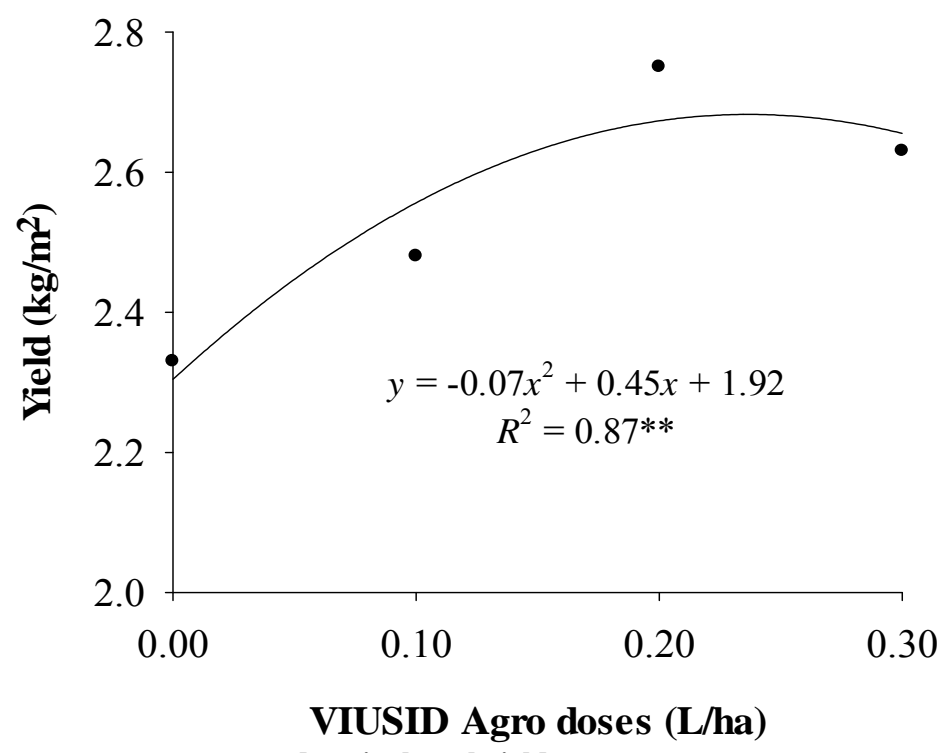

Fig. 1 Polynomial ratio between treatments and agricultural yield.

** Significant at $99 \%$ of probability level.

to the control. There were no significant differences between treatments in the harvest index (Table 5). As regards the agricultural yield, the most favourable behaviour was achieved with the $0.2 \mathrm{~L} / \mathrm{ha}$ and 0.3 $\mathrm{L} / \mathrm{ha}$ dosages, with significant differences between the lower dosage and the control. The increases were 0.42 $\mathrm{kg} / \mathrm{m}^{2}$ and $0.30 \mathrm{~kg} / \mathrm{m}^{2}$, representing $18.03 \%$ and $12.88 \%$ of yield, respectively. The best model was selected due to a determination coefficient of $R^{2}>0.80$. The model of best fit was a polynomial of degree two. In the trend line it is observed that the yield increases with the dosages, up to a point where it then decreases (Fig. 1).

The performance in the increase of production is due to the foliar application of the VIUSID agro growth enhancer. This product contains several elements that may positively influence this result. Among them are amino acids, which are considered precursors and components of proteins that are important for the stimulation of cell growth [20]. They act as dampers that help maintain favourable $\mathrm{pH}$ values within plant cells [21]. Moreover, they are bio-stimulants, and it is well known that application of formulas containing amino acids has positive effects on plant growth and yield and significantly reduces injuries caused by abiotic stress [22].

Another element of great importance in the composition of VIUSID agro is $\mathrm{Zn}$, which has been reported to play a part in fruit set or fill and plant growth. Various authors have stated that when $\mathrm{Zn}$ is 
applied, alone or in combination with other nutrients in formulas for agricultural use, favourable results have been obtained [23].

However, there were several investigations that assert the product's effectiveness on other crops [9], where favourable results were obtained with regards to the number of leaves per plant and leaf thickness and length in an anthurium crop (A. andreanum Lind.). These authors carried out a weekly foliar application using different dosages of the product and reported not only benefits to the vegetative growth of the crop, but also an accelerated onset of flowering. Other authors reported satisfactory results in several crops when using VIUSID agro. Some examples are in the grass yield [7, 8], tomato crop [10], in corn and onions [11, 12]. In tobacco seedlings [24], an increase in the size and number of leaves, length and thickness of the stalk, as well as usable seedlings per square metre was found. The authors of this article applied VIUSID agro to foliage on a weekly basis until $7 \mathrm{~d}$ before harvest and determined that the $0.2 \mathrm{~L} /$ ha dosage had the greatest stimulating effects.

\section{Conclusions}

The VIUSID agro growth promoter positively influences the morphophysiological indicators of pak choi crops. The most favourable behaviour was obtained at the $0.2 \mathrm{~L} / \mathrm{ha}$ and $0.3 \mathrm{~L} / \mathrm{ha}$ dosages. Foliar application of VIUSID agro does not increase harvest index at the dosages used.

\section{References}

[1] Oliveira, R. A., Oliveira, F. A., Medeiros, J. F., Sousa, V. F. L., and Freire, A. G. 2014. "Interaction between Salinity and Phosphorus in Radish Culture." Journal of Agronomy. Science 41 (4): 519-26. (in Portugués)

[2] Marcos, F., and Kikuti, R. 2006. "The Radish Cultivation of World Importance.” Accessed October 12, 2010. http://repositorio.umsa.bo/bitstream/handle/sequence $=1 / 2$ 547htre6ue.

[3] Rodríguez, A., Companioni, N., Peña, E., Cañet, P., Fresneda, J., Estrada, J., and Rey, R. 2007. Technical Manual for Organoponic, Intensive Orchards and Semi-protected Organopony. 6th ed. Havana: Ministry of
Higher Education, 184. (in Spanish)

[4] Martínez, M. de los A., Ceballos, M., Suris, M., Duarte, L., and Baños, H. 2013. "Aphids and Their Parasitoids in Urban Vegetable Production Systems in Cuba." Colombian Journal of Entomology 39 (1): 13-7. (in Spanish)

[5] ONE. 2015. Agriculture, Forestry and Fishing. Agricultural Production by Selected Crops. Edition 2015, Ministry of Higher Education, 33. (in Spanish)

[6] Catalysis. 2014. "VIUSID Agro, Promoter of Growth." Accessed March 20, 2014 http://www.catalysisagrovete.com. (in Spanish)

[7] Galdo, Y., Quintana, M., Cancio, T., and Méndez, V. 2014. "Use of Agro VIUSID to Stimulate Growth in Three Grasses." In Memories III International Agrodesarrollo Convention 2014. Varadero, Cuba. (in Spanish)

[8] Quintana, M., Galdo, Y., Cancio, T., and Mendez, V. 2015. "Effect of the Natural Stimulant VIUSID Agro in the Production of Forage Biomass of Hybrid Brachiaria cv. Mulatto II." Agrotecnia of Cuba 39 (5): 15-22. (in Spanish)

[9] Peña, K., Rodriguez, J. C., and Melendrez, J. F. 2015. "Effect of the Application of a Molecularly Activated Growth Promoter in the Culture of Anthurium andreanum Lind." Granma Sciences Journal 19 (2): 1-12. (in Spanish)

[10] Peña, K., Rodriguez, J. C., and Melendrez, J. F. 2016. "The VIUSID Agro: An Alternative in the Increase of the Production of Tomato (Solanum lycopersicum L.)." Caribbean Journal of Social Sciences 15 (5): 1-10. (in Spanish)

[11] Atta, M., Abdel-Lattif, M., and Absy, R. 2017. "Influence of Biostimulants Supplement on Maize Yield and Agronomic Traits." Bioscience Research 14 (3): 604-15.

[12] Melendrez, J. F., Peña, K., and Cristo, M. 2016. "Effect of Three Doses of VIUSID Agro on the Cultivation of Onion (Allium cepa L.) in the Municipality of Taguasco." Infociencia 20 (3): 1-12. (in Spanish)

[13] Peña, K., Rodriguez, J. C., Olivera, D., Melendrez, J. F., Rodriguez, L., Valdez, R., and Rodríguez, L. 2017. "Effects of Growth Promoter on Different Vegetable Crops.” Int. J. Dev. Res. 7 (2): 11737-43.

[14] Peña, K., Rodríguez, J. C., Olivera, D., Calero, A., Meléndrez, J. F., and García, R. 2018. "Effect of VIUSID Agro ${ }^{\circledR}$ Dose on the Morpho-Physiological and Productive Behavior of Radish (Raphanus sativus L.)." Rev. Fac. Agron. 35 (3): 293-317. (in Spanish)

[15] Fuentes, F. E., Abreu, E., Fernández, E., and Castellanos, M. 1999. Agricultural Experimentation, edited by Félix Varela. Havana, Cuba: Ministry of Higher Education, 225. (in Spanish) 
[16] Huerres, C., and Carballo, N. 1996. Horticulture. Havana: Editorial People and Education, 193. (in Spanish)

[17] Gardner, F. P., Pearce, R. B., and Mitchell, R. L. 2003. Physiology of Crop Plants. Iowa: Blackwell Publishing Company, 326.

[18] SPSS. 2006. Statistical Package for the Social Sciences (SPSS), Version 15.0.1. Chicago, USA: SPSS Inc.

[19] MINITAB. 2003. Statistical Software Minitab Release 14.12.0. Pennsylvania, USA: Minitab Inc.

[20] Rai, V. K. 2002. "Role of Amino Acids in Plant Responses to Stress.” Biol Plant. 45 (2): 471-8.

[21] Davies, D. D. 1982. "Physiological Aspects of Protein Turn Over.” Encycl Plant Physiol. 45: 481-7.

[22] Kowalczyk, K., and Zielony, T. 2008. "Effect of Aminoplant and Asahi on Yield and Quality of Lettuce
Grown on Rockwool." Presented at Conference of Biostimulators in Modern Agriculture, Warsaw, Poland.

[23] Sawan, Z. M., Mahmoud, H. M., and El-Guibali, A. H. 2008. "Influence of Potassium Fertilization and Foliar Application of Zinc and Phosphorus on Growth, Yield Components, Yield and Fiber Properties of Egyptian Cotton (Gossypium barbadense L.).” J. Plant Ecol. 1 (4): 259-70. doi: 10.1093/jpe/rtn021.

[24] Peña, K., Rodríguez, J. C., Olivera, D., Calero, A., Dorta, R., Meléndrez, J. F., Veloso, Y. F., and Kukurtcu, B. 2018. "Effect of the Growth Promoter VIUSID Agro on the Morphophysiological and Productive Performance of Tobacco Growth (Nicotiana tabacum L.).” J. Agric. Sci. $\begin{array}{lllll}\text { Technol. } \quad B & 8 & \text { (3): } & 67-177 . & \text { doi: }\end{array}$ 10.17265/2161-6264/2018.03.003. 